\author{
JANUARY 2017, VOLUME 5, ISSUE 1, 16 - 28 \\ E-ISSN NO: $2289-4489$
}

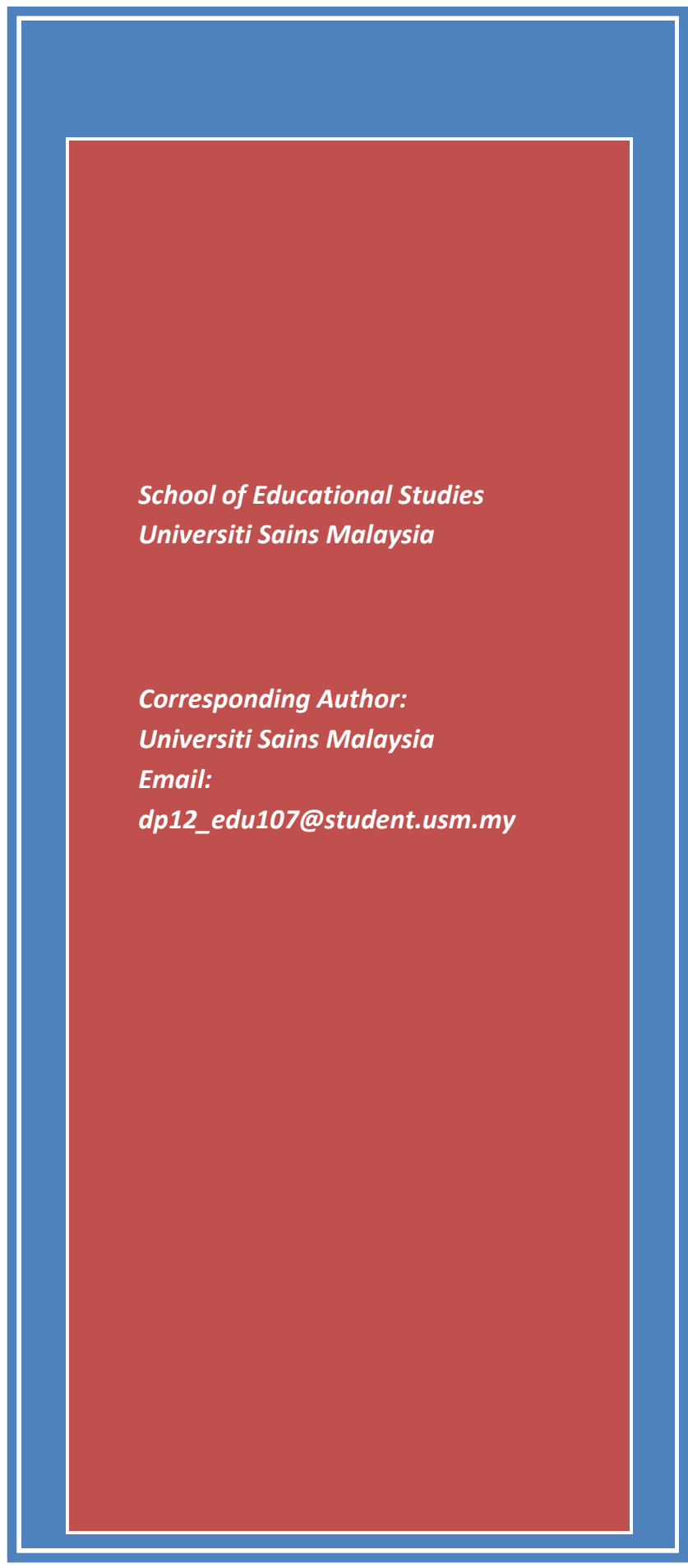

\section{INDIGENOUS STUDENTS' CHALLENGES, ADAPTATION AND SELF- ESTEEM DURING POST-SECONDARY EDUCATION: A STUDY ON SELECTED MALAYSIAN PUBLIC UNIVERSITIES}

Doreen Primus, Melissa Ng Lee Yen Abdullah (PhD) \& Aziah Ismail (PhD)

\section{ABSTRACT}

Past studies showed that indigenous students are underrepresented in higher education and they tend to have lower academic performance and are more atrisk of dropping out compared to non-indigenous students. Because of the scarcity of local studies, the specific challenges faced by indigenous students during postsecondary education in the Malaysian context are unclear. Indigenous students may encounter various psychological and non-psychological challenges. They are regarded as having significantly lower adaptation and are more prone to psychological problems, such as low self-esteem, compared to the nonindigenous students. These challenges often lead to lower academic achievement, which eventually resulted in withdrawal from the higher education institution. Hence we need to explore the challenges and psychological issues faced by indigenous students during postsecondary education in Malaysia. This study aims at filling in the literature gap by conducting a study on indigenous students at three selected Malaysian public universities. Because the research problem is a fairly unchartered area, a mixed method sequential explanatory study was employed for a better understanding of the research problem. Twelve indigenous students and 2 administrators were chosen for the in-depth semistructured interviews. Thematic analysis was employed to analyze qualitative data. To further understand these challenges according to students' demographic profile, 51 indigenous students were chosen to respond to questionnaires. The instruments used are the Adaptation Scale by Baker and Siryk (1989) and Self-Esteem Scale by Heatherton and Polivy (1991). The quantitative data were analyzed using SPSS version 21.0. Findings showed that social and academic adaptation and self-esteem were issues among the indigenous students. In addition, transitions into university and new programs may also pose certain challenges to indigenous students as first-year students and those enrolled in pre-diploma programs were found to have lower adaptation and self-esteem compared to their seniors. Low self-esteem seems to be a persistent issue cutting across all demographic profiles.

Keywords: Indigenous student, Self-esteem, Challenges, Adaptation, Higher education, Malaysia 


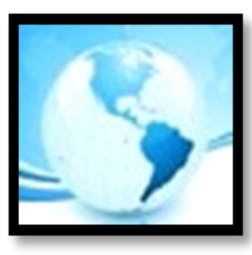

\section{INTRODUCTION}

Given the inadequate local studies on indigenous students, the specific challenges they faced during postsecondary education in the Malaysian context are unclear. Past study shows indigenous students are mostly underrepresented in higher education because of their disadvantaged socio-economic backgrounds (Biddle \& Cameron, 2012). A number of institutional measures have been taken over the past decades to increase the participation and completion rates of indigenous students in postsecondary education (Pechenkina, Kowal, \& Paradies, 2011). Nevertheless, their participation and educational outcomes remain persistently low globally. In Malaysia, indigenous student enrolment at local postsecondary institutions had improved gradually but the numbers still remain small (Table 1). Their participation rate in higher education was only around $0.31 \%$. As shown in Table 1, in 2015 a total of 570 indigenous students were enrolled at the 21 public HEls in Malaysia ( $n=362$ diploma students; $\mathrm{n}=208$ bachelor degree students) (Mohd Noorazli, 2015).

Table 1

The number of Indigenous Students Enrolled into Higher Institution (2014 and 2015)

\begin{tabular}{llllll}
\hline No & Public Higher Education Institutions & $\mathbf{2 0 1 4}$ & $\mathbf{2 0 1 5}$ \\
\cline { 3 - 6 } & & Diploma & Bachelor & Diploma & Bachelor \\
\hline 1 & Universiti Malaya (UM) & - & 9 & 5 & 12 \\
2 & Universiti Sains Malaysia (USM) & - & 7 & - & 8 \\
3 & Universiti Kebangsaan Malaysia (UKM) & 7 & 7 & - & 14 \\
4 & Universiti Putra Malaysia (UPM) & 4 & 5 & 3 & 14 \\
5 & Universiti Teknologi Malaysia (UTM) & - & & - & 6 \\
6 & Universiti Utara Malaysia (UUM) & - & 12 & - & 10 \\
7 & Universiti Malaysia Sabah (UMS) & - & 7 & - & 13 \\
8 & Universiti Malaysia Sarawak (UNIMAS) & - & 5 & - & 4 \\
9 & Universiti Islam Antarabangsa Malaysia (UIAM) & 19 & 17 & 38 & 4 \\
10 & Universiti Pendidikan Sultan Idris (UPSI) & - & 4 & - & 6 \\
11 & Universiti Malaysia Kelantan (UMK) & 185 & 48 & 202 & 65 \\
12 & Universiti Teknologi MARA (UiTM)* & 3 & 17 & 2 & 7 \\
13 & Universiti Sultan Zainal Abidin (UniSZA) & 6 & 19 & 5 & 9 \\
14 & Universiti Tun Hussein Onn Malaysia (UTHM) & 4 & 6 & 6 & 5 \\
15 & Universiti Teknikal Malaysia Melaka (UTeM) & 8 & 7 & 7 & 8 \\
16 & Universiti Malaysia Pahang (UMP) & - & 6 & - & 8 \\
17 & Universiti Malaysia Terengganu (UMT) & - & - & 1 & 5 \\
18 & Universiti Malaysia Perlis (UniMAP) & - & 2 & - & - \\
19 & Teachers' College & 91 & - & 86 & - \\
20 & Polytechnic & - & - & - & - \\
21 & Community College & 334 & 201 & 362 & 208 \\
\hline & Total & & & & \\
\hline
\end{tabular}

Source. Mohd Noorazli (2015)

\section{Transition into Postsecondary Education}

Transition from secondary school to higher education is often complicated, even for those non-indigenous students. Md Kail (personal communication, August 27, 2015) reported that underprivileged learners such as indigenous students face huge obstacles, when enrolling into university in Malaysia. Culture shock, connecting with faculty members and lack of social involvement contribute significant effect on the adaptation of indigenous 


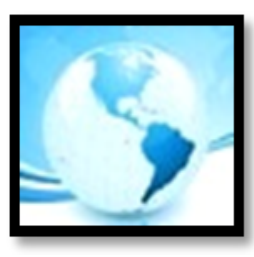

\section{MALAYSIAN ONLINE JOURNAL OF EDUCATIONAL MANAGEMENT (MOJEM)}

students in the new environment (Primus \& Abdullah, 2015). Anderson, Goodman, and Schlossberg (2012) explain in the Transition Theory that as the students experience the transition process, they will be aware of their assets and liabilities which are affected by four factors (1) Situation, (2) Self, (3) Support and (4) Strategies. The students will first assess the situation when entering university and perceive it as either a positive or negative situation (Situation). Their personal demographic features (Self) such as gender, socioeconomic status, and stage of life, state of health, and ethnicity, and age directly affect how they perceive and assess life at the university. In addition, the social support (Support) that they receive, which is frequently observed as the key to managing stress can also affect the transition process. For example in one of the universities, indigenous students reported that institutional support offers a great deal for them to stay at the university (Hasni, personal communication, August $27,2015)$. These supports may come from other students, lecturers, university staff, local community and relevant agencies. Lastly, three main coping responses have been identified during the transition process; responses that modify the situation, reaction that rule the sense of the crisis, and feedback that helps the person manage stress during transition (Strategies). The theory provides a framework for understanding students' experiences, challenges and adaptation during transitions into higher education.

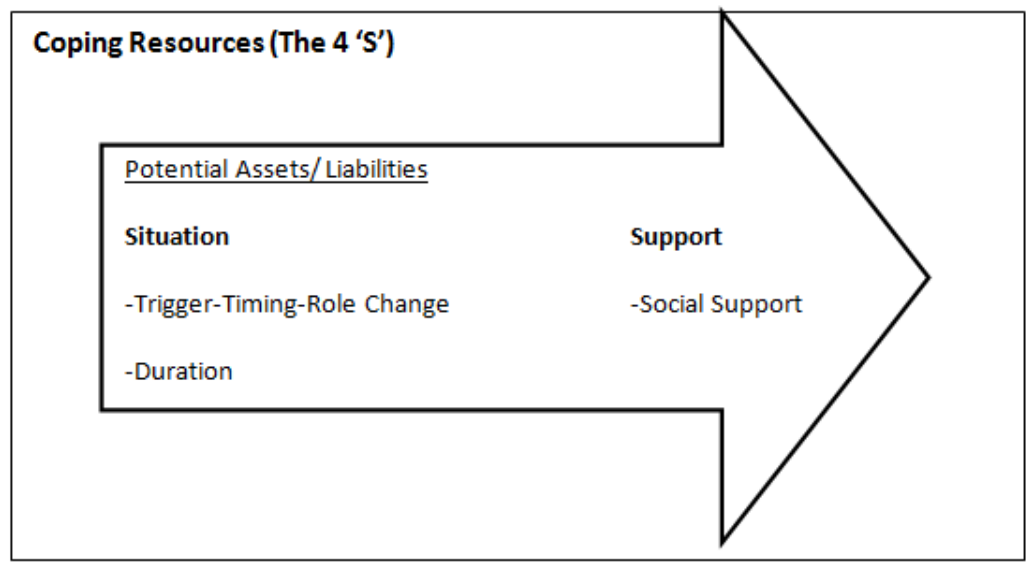

Figure 1: The Transition Process (Adapted from Anderson, Goodman \& Schlossberg, 2012, p. 39)

\section{Indigenous Students' Adaptation and Self-Esteem}

According to Graff (2011), adaptation in higher education refers to issues face by students in the area of academic, social and emotional adaptations during higher education. Academic adaptations are mostly about making connections between a variety of academic factors and the students' performance while studying in the university. Social and emotional adaptations, on the other hand, refer to students' abilities to adapt to the environment during social interactions with peers and staff at the university and their emotional wellbeing (Sullivan, 2008). Students who receive support during the transition process are able to adapt better socially and emotionally, hence leading to better academic performance. The indigenous students in one of the Malaysian public universities reported having low self-esteem that may generate poor academic performance and dropout in the long run (Primus \& Abdullah, 2015). On the contrary, those who cope with the new situation will face greater challenges in performing and completing their postsecondary education (Sullivan, 2008).

Cross-cultural adaptation seems to be a challenging issue for first year to final year students (Lenzerini, 2010). Lai (2014), however, stated that this may not be the case if first-year postsecondary students are able to adapt 


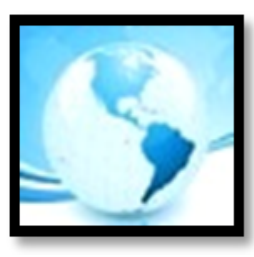

socially, personal-emotionally and academically. This is because a smooth transition into higher education will enable the students to adapt gradually and persist in the face of considerable obstacles. Generally, indigenous students have disadvantaged backgrounds compared to their non-indigenous peers. They have poorer self-esteem and face greater stigmatization during university life, which affect their adaptation negatively (Gallop \& Bastien, 2016). The literature gap needs to be filled in due to the scarcity of studies on the unique challenges faced by indigenous students during postsecondary education in the Malaysian context. To fill in the literature gap, this study aims at exploring the challenges face by indigenous students at selected Malaysian public universities. It also aims at gauging indigenous students' adaptation and self-esteem empirically according to students' demographic profile. It also determines the relationships between adaptation and self-esteem since literature reviews suggest these two variables are related (e.g., Cho, Mallinckroft \& Yune, 2010).

\section{METHODOLOGY}

\section{Research Design}

Indigenous students' challenges during postsecondary education in Malaysia are a largely unchartered research area. Hence, a mixed method sequential explanatory design was used to collect data for this study. This approach was used to provide a better understanding of the research problem (Creswell, 2013). The design collected qualitative data at one level and quantitative data at another level in a sequential manner to answer interrelated research questions (Ivonkova, Creswell, \& Stick, 2006). Both types of data were analyzed accordingly, and the results were used to make multiple types of inferences. Both qualitative and quantitative data were collected at three public universities in Malaysia. The public universities were chosen as they offer pre-diploma, diploma and degree programs (Mohd Noorazli, 2015).

\section{Sampling}

Table 2 shows the distribution of indigenous students sampled in this study from three selected public universities. University $1^{1}$ has two degree students and 13 diploma students. University $2^{2}$ has six degree students while University $3^{3}$ has 16 diploma and 14 pre-diploma students.

Table 2

Distribution of Indigenous Students according to Selected Malaysian Public Universities

\begin{tabular}{|c|c|c|c|c|}
\hline No & Selected Malaysian Public Universities* & Bachelor & Pre-diploma & Total \\
\hline 1 & University 1 & 213 & - & 15 \\
\hline 2 & University 2 & 6 & - & 6 \\
\hline \multirow[t]{2}{*}{3} & University 3 & 16 & 14 & 30 \\
\hline & Total & 29 & 14 & 51 \\
\hline
\end{tabular}

Source. Mohd Noorazli (2015); * The names of the universities were kept anonymous

The demographic profile of indigenous students sampled from the three public universities is shown in Table 2. The study collected four demographic data from the indigenous students through a questionnaire survey. The demographic data collected include gender, first-generation, level of study and year of study (Table 3).

In order to choose the interview participants, indigenous students was first identified from the respective university's Student Affair Department records. Twelve $(n=12)$ indigenous students with diverse demographic 


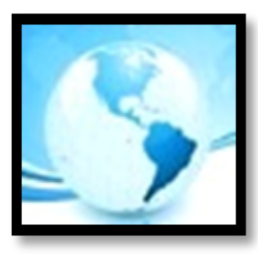

backgrounds (e.g., gender, level of study, disciplines and academic performance) were interviewed while 51 indigenous students were involved in the quantitative study.

Majority of the respondents were female $(78 \%, n=40)$, first generation students $(74 \%, n=38)$, diploma students $(56 \%, n=29)$ and were in their first year university study $(41 \%, n=21)$.

Table 3

Respondents' Demographic Profile

\begin{tabular}{cll}
\hline Demographic & No. of Participants (n) & Percentage (\%) \\
\hline Gender & & \\
$\bullet \quad$ Male & 11 & 22 \\
- Female & 40 & 78 \\
First-Generation & & 74 \\
- Yes & 38 & 26 \\
\hline$\quad$ No & 13 & \\
Level of Study & & 27 \\
- Pre-Diploma & 14 & 56 \\
- Diploma & 29 & 17 \\
Year of Study & 8 & \\
- First Year & & 41 \\
- Second Year & 21 & 21 \\
- Third Year & 11 & 17 \\
\hline
\end{tabular}

\section{Instrument}

A questionnaire was used to collect quantitative data from the indigenous students to further analyze and understand the challenges they faced according to their demographic profile. Indigenous students' adaptation was measured by the Adaptation Scale, adapted from Baker and Siryk's original scale (1989). The instrument has 55 items and an alpha value of $\alpha=.91$. Indigenous students' self-esteem, on the other hand, was gauged by the SelfEsteem Scale, adapted from Heatherton and Polivy (1991). It has 16 items and an alpha value of $\alpha=.91$. Both instruments were translated into Malay language and the responses were recorded into four point Likert scales.

\section{Data Collection Procedure}

Official approvals were obtained from the Department of Orang Asli Development (JAKOA), the Education Planning and Research Division (EPRD) and the selected universities before the study was carried out.

Data collection was carried out in two phases. In the first phase, in-depth interviews were carried out with 12 indigenous students and 2 staff members at the university to explore the challenges faced by the students during postsecondary education. Semi-structured interviews were conducted to gather the narrative data. To further investigate the challenges identified in the qualitative finding and to analyze these challenges according to the students' demographic profile, a quantitative study was conducted in phase two of the research. A total of 51 indigenous students have participated in the survey. 


\section{Data Analysis}

The qualitative data gathered from the interviews were analyzed using thematic analysis technique. Thematic analysis is one of the most common forms of analysis in qualitative research, which is appropriate for study that seeks to explore new research areas. Thematic analysis allows the researchers to determine precisely the relationships between concepts and compare them with the replicated data. Patterns across the interview transcripts were analyzed to identify common themes and provide explanation for the research problems, in this case, to understand the challenges, adaptation and self-esteem of indigenous students in public universities. Quantitative data analysis, on the other hand, involved descriptive statistics, specifically, Mean (M) and Standard Deviation $(S D)$, Frequency $(F)$ and Percentages (\%). Descriptive analysis provides very useful examination on indigenous students' adaptation and self-esteem across the five demographic profiles (gender, first-generation, level of study, and year of study). The quantitative data were analyzed using SPSS version 21.0.

\section{FINDINGS}

The findings of the study were discussed in relation to the two main objectives of the study. The first objective was to explore the challenges face by indigenous students at selected Malaysian public universities. The findings provide a basis to gauge indigenous students' adaptation and self-esteem empirically. The second objective was to further understand indigenous students' adaptation and self-esteem issues by taking into account their demographic profile. The relationships between adaptation and self-esteem were also analyzed and discussed.

\section{Challenges Faced by Indigenous Students in Postsecondary Education}

Based on the thematic analysis on the data transcription (Table 4), three (3) main themes have emerged; socioemotional adaptation, academic adaptation and self-esteem. Social barriers experienced by the indigenous students also caused them to have low self-esteem. Indigenous students struggled to adapt to the mainstream culture at the university even though they have tried to interact with non-indigenous students. The findings of this study revealed that indigenous students acknowledged that they have low self-esteem and suffered from inferiority complex. According to the students, they felt intimidated by the non-indigenous peers. "Indigenous...cannot interact with other non-indigenous. [They are] shy and not confident...but fine when interacting with indigenous friends". The indigenous students also added, "During my first semester, it was difficult for me to adapt ... with others at the university. When they (non-indigenous students) know that we are indigenous people, they underestimate us." The statement suggests that the indigenous students felt that they were being underestimated and undermined when non-indigenous students found out that they were indigenous people. The fear of judgment arises when indigenous students have to introduce themselves to new course mates or acquaintances, which became a barrier to their socialization in the campus.

Table 4

Challenges Faced by Indigenous Students at Postsecondary Education

\begin{tabular}{|l|l|l|l|}
\hline SELECTED STATEMENTS* & KEYWORD & SUBTHEME & THEME \\
\hline $\begin{array}{l}\text { [There are some who] do not wish to study } \\
\text { but their parents insisted. [As a result] they } \\
\text { come to university to waste time and money. }\end{array}$ & -parents insisted to study & Cultural Barrier & $\begin{array}{l}\text { Socio- } \\
\text { Emotional } \\
\text { Adaptation }\end{array}$ \\
\hline
\end{tabular}




\begin{tabular}{|c|c|c|c|}
\hline $\begin{array}{l}\text { Indigenous people are not open-minded } \\
\text { about education. They [insist on] working to } \\
\text { get money. [Their] parents insist their } \\
\text { children work and get money. Work around } \\
\text { the village. [They are] not serious about this } \\
\text { opportunity because of their parents. Their } \\
\text { parents think that if their children go out } \\
\text { from the village to study, they are up to no } \\
\text { good. }\end{array}$ & $\begin{array}{l}\text {-Not open-minded } \\
\text {-Their parents insist their } \\
\text { children to work } \\
\text { - Not serious about this } \\
\text { opportunity. } \\
\text {-Their parents think that } \\
\text { their children are up to no } \\
\text { good. }\end{array}$ & & \\
\hline $\begin{array}{l}\text { Malays are majority in the university [We } \\
\text { have to] acknowledge them first or else they } \\
\text { do not bother about our existence. [Since] I } \\
\text { am the only indigenous male in my block, I } \\
\text { do not have friends. Other [indigenous] } \\
\text { friends stayed in different block. }\end{array}$ & -no friends & \multirow[t]{3}{*}{$\begin{array}{l}\text { Social } \\
\text { Interaction } \\
\text { Issues }\end{array}$} & \\
\hline $\begin{array}{l}\text { [I] initiate the interaction with other people. } \\
\text { We have to start first if not they will never } \\
\text { bother our existence for the rest of the } \\
\text { semester. }\end{array}$ & $\begin{array}{l}\text { - initiate the interaction } \\
\text { with other people }\end{array}$ & & \\
\hline $\begin{array}{l}\text { [We] have to interact with other people. But } \\
\text { not until we neglect our studies. }\end{array}$ & $\begin{array}{l}\text {-have to interact to other } \\
\text { people }\end{array}$ & & \\
\hline $\begin{array}{l}\text { During my first semester, it is difficult to } \\
\text { adapt with others at university. When they } \\
\text { (other students) know that we are indigenous } \\
\text { people they underestimate us. }\end{array}$ & $\begin{array}{l}\text {-underestimate } \\
\text {-difficult to adapt }\end{array}$ & $\begin{array}{l}\text { Fear of people } \\
\text { judgment }\end{array}$ & \\
\hline $\begin{array}{l}\text { [They] cannot cope. [They] cannot score so } \\
\text { they were dismissed. [They] are lazy. Not } \\
\text { studying properly. [That] is their attitude. }\end{array}$ & $\begin{array}{l}\text { - cannot cope } \\
\text { - lazy } \\
\text { - attitude }\end{array}$ & \multirow[t]{5}{*}{$\begin{array}{l}\text { Lacking in Self- } \\
\text { Regulation }\end{array}$} & \multirow[t]{5}{*}{$\begin{array}{l}\text { Academic } \\
\text { Adaptation }\end{array}$} \\
\hline $\begin{array}{l}\text { [I have] trouble studying independently. I } \\
\text { need reinforcement from others[ lecturer } \\
\text { and classmate] }\end{array}$ & - reinforcement & & \\
\hline $\begin{array}{l}\text { I don't understand the content of my course. } \\
\text { The [assignment] is difficult to understand. }\end{array}$ & -difficult & & \\
\hline $\begin{array}{l}\text { The examination paper [of my course] is very } \\
\text { different from what I learn in class. [I] think I } \\
\text { am not paying enough attention in class. }\end{array}$ & $\begin{array}{l}\text { - not paying enough } \\
\text { attention }\end{array}$ & & \\
\hline $\begin{array}{l}\text { They [indigenous students] think academic is } \\
\text { important but less effort to succeed. }\end{array}$ & - less effort & & \\
\hline
\end{tabular}




\begin{tabular}{|c|c|c|c|}
\hline $\begin{array}{l}\text { English Language [the most difficult one]. } \\
\text { [English] is the medium in the university. [we] } \\
\text { are really stressed when it comes to doing } \\
\text { assignments [in English] }\end{array}$ & English language & $\begin{array}{l}\text { Language } \\
\text { Barrier }\end{array}$ & \\
\hline $\begin{array}{l}\text { Academically (at the university) I struggle. It } \\
\text { is difficult for me to understand the lesson. } \\
\text { Others (students) normally wanted bright } \\
\text { students to be in their group discussion. Since } \\
\text { I was not bright, I would be isolated (lack of } \\
\text { academic proficiency). }\end{array}$ & $\begin{array}{l}\text {-struggle } \\
\text {-difficult for me to } \\
\text { understand the lesson } \\
\text {-lack of academic } \\
\text { proficiency }\end{array}$ & \multirow[t]{2}{*}{$\begin{array}{l}\text { Lack of } \\
\text { proficiency }\end{array}$} & \\
\hline $\begin{array}{l}\text { I was called up by a counselor because of my } \\
\text { academic has not been satisfactory in three } \\
\text { semesters. Counselors motivate me (to } \\
\text { strive). Difficult for me to understand even } \\
\text { though the lesson has been repeated (due to } \\
\text { lack of proficiency) }\end{array}$ & $\begin{array}{l}\text {-academic has not been } \\
\text { satisfactory } \\
\text {-difficult to understand } \\
\text {-lack of language } \\
\text { proficiency }\end{array}$ & & \\
\hline $\begin{array}{l}\text { I feel that other [non-indigenous students] } \\
\text { [think that] we are worthless to be friends } \\
\text { with [because we are different from them] }\end{array}$ & -worthless & \multirow[t]{2}{*}{ Inferiority } & \multirow[t]{5}{*}{$\begin{array}{l}\text { Low Self- } \\
\text { Esteem }\end{array}$} \\
\hline $\begin{array}{l}\text { [Indigenous students] quite difficult to mix } \\
\text { with others [non-indigenous students], } \\
\text { [indigenous students] possess inferiority } \\
\text { complex, very low self-esteem. }\end{array}$ & -inferiority & & \\
\hline $\begin{array}{l}\text { Indigenous who cannot interact with other } \\
\text { non-indigenous. [They are] shy and lacking } \\
\text { in confidence... but fine when interacting } \\
\text { with indigenous friends. }\end{array}$ & - shy & $\begin{array}{l}\text { Lack of } \\
\text { Confidence }\end{array}$ & \\
\hline $\begin{array}{l}\text { I do experience low self-esteem because it is } \\
\text { difficult to mingle (at the university). Difficult } \\
\text { because we are minority (indigenous } \\
\text { students at university) }\end{array}$ & $\begin{array}{l}\text {-low self-esteem } \\
\text {-difficult to mingle }\end{array}$ & \multirow[t]{2}{*}{$\begin{array}{l}\text { Intimidated and } \\
\text { fear of } \\
\text { judgment }\end{array}$} & \\
\hline $\begin{array}{l}\text { I do feel (low self-esteem, intimidated). It is } \\
\text { very difficult for other people to mingle with } \\
\text { indigenous students. I feel it is difficult to } \\
\text { adapt (at the university). Other people may } \\
\text { not have confidence in us (mingling and } \\
\text { communicating). }\end{array}$ & $\begin{array}{l}\text {-low self-esteem } \\
\text {-intimidated } \\
\text {-difficult to adapt }\end{array}$ & & \\
\hline
\end{tabular}

Note. The selected statements were translated into English 


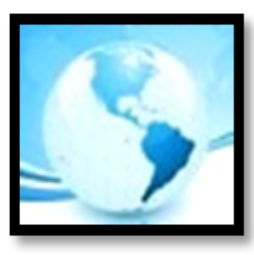

The indigenous students mainly struggle with academic issues due to their lack of academic competency and language proficiency. The indigenous students recalled "I was called up by a counselor because of my academic has not been satisfactory in three semesters. Counselors motivate me [to strive]. Difficult for me to understand even though the lesson has been repeated". Furthermore, lacking in academic competency also cause them to experience isolation from others. The indigenous students' reported "Academically [at the university] I struggle. It is difficult for me to understand the lesson. Others [students] normally wanted bright students to be in their group discussion. Since I was not bright, I would be isolated".

The officers from the universities agreed that most of the indigenous students at their university have lower academic competency than their non-indigenous peers. "[They] cannot cope. [They] cannot score so they were dismissed. [They] are lazy. Not studying properly. [That] is their attitude". They added, "English Language [the most difficult one]. [English] is the medium in the university. [We] are really stressed when it comes to doing assignments [in English]". At this particular university, the medium of instruction (English Language) at the university hinders them from striving in academic.

Moreover, self-esteem seems to be affecting indigenous students' participation in university activities. According to the students, "I do experience low self-esteem because... it is difficult to mingle [at the university]. Difficult because we are minority [indigenous students at university]". Feeling intimidated by non-indigenous peers also causes a barrier in socializing at the university. "I do feel [low self-esteem, intimidated]. It is very difficult for other people to mingle with indigenous students. I feel it is difficult to adapt [at the university]. Other people may not have enough confidence in us". From the officer's perspective, they concluded that indigenous students felt inferior which holds them back to mingle at the university. They said, "[Indigenous students] quite difficult to mix with others [non-indigenous students], [indigenous students] possess inferiority complex, very low self-esteem". Moreover, the officers have the same opinion about the indigenous students' interaction problems. They concurred, "Indigenous [students] who cannot interact with other non-indigenous. [They are] shy and lack of confidence...but fine when interacting with indigenous friends.

Figure 2 shows the graphical representation of the thematic analysis. As a whole, the thematic analysis revealed that the main challenges faced by the indigenous students at university were social and academic adaptations as well as issues of low self-esteem.

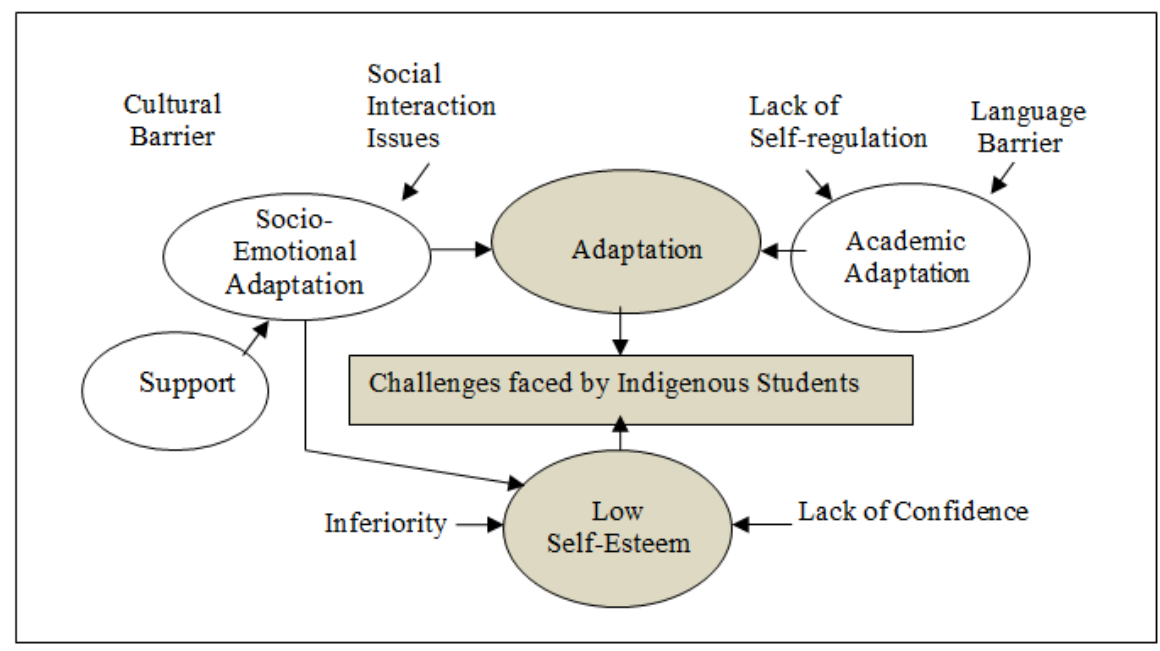

Figure 2: Thematic Analysis on Challenges Faced by Indigenous Students Support 


\section{Descriptive Analysis on Adaptation and Self-Esteem}

To further analyze and triangulate findings obtained from the qualitative analysis, adaptation and self-esteem of the indigenous students were gauged empirically using the Adaptation Scale and Self-Esteem Scale. This will allow the adaptation and low self-esteem issues to be analyzed according to the students' demographic profile. Table 5 shows the adaptation and self-esteem of indigenous students according to demographic profile. As seen in Table 5, males have better adaptation and self-esteem compared to females. First-generation students have slightly lower adaptation and self-esteem compared to non-first-generation students. Pre-diploma also showed slight lower adaptation and self-esteem compared to diploma students. Degree students have better adaptation and selfesteem compared to diploma and pre-diploma students. The findings indicate that adaptation and self-esteem issues may be more prone among female and first-generation indigenous students. In addition, transitions into university and enrollment into new program seems to pose certain challenges to the students as first-year indigenous and pre-diploma students were found to have lower adaptation and self-esteem compared to their seniors.

Table 5

Adaptation and Self-esteem of Indigenous Students according to Demographic Profile

\begin{tabular}{|c|c|c|c|c|c|}
\hline & & \multicolumn{2}{|c|}{ Adaptation } & \multicolumn{2}{|c|}{ Self-Esteem } \\
\hline & & $M$ & $S D$ & $M$ & $S D$ \\
\hline \multicolumn{6}{|c|}{ Gender } \\
\hline & Male $(n=11)$ & 3.13 & .07 & 2.12 & .37 \\
\hline & Female $(n=40)$ & 2.80 & .19 & 2.00 & .17 \\
\hline \multicolumn{6}{|c|}{ First-Generation } \\
\hline & Yes $(n=38)$ & 3.04 & .16 & 2.07 & .23 \\
\hline & No $(n=13)$ & 3.81 & .20 & 2.42 & .15 \\
\hline \multicolumn{6}{|c|}{ Level of Study } \\
\hline & Pre-Diploma $(n=14)$ & 3.51 & .14 & 2.12 & .20 \\
\hline & $\operatorname{Diploma}(\mathrm{n}=29)$ & 3.76 & .18 & 2.30 & .23 \\
\hline & Degree $(n=8)$ & 3.80 & .22 & 2.32 & .29 \\
\hline \multicolumn{6}{|c|}{ Year of Study } \\
\hline & First Year $(n=21)$ & 2.23 & .15 & 2.02 & .22 \\
\hline & Second Year $(n=11)$ & 2.74 & .20 & 2.24 & .25 \\
\hline & Third Year $(n=8)$ & 2.76 & .13 & 2.27 & .17 \\
\hline & Fourth Year $(n=11)$ & 3.32 & .19 & 2.44 & .23 \\
\hline
\end{tabular}

Note: $S D=$ Standard Deviation

One of the key findings from the descriptive analysis (Table 5) was that regardless of gender, level of study, year of study and whether the students are first-generation students or not, their self-esteem was consistently low. The findings in Table 5 also show that poor self-esteem, a lack of confidence and inferiority was common issues of indigenous students. This was aggravated by their poorer academic performance and disadvantaged socioeconomic backgrounds compared to non-indigenous peers. Low self-esteem experienced by the indigenous students was closely related to their socio-economic backgrounds. Hence, overcoming these challenges has proven 


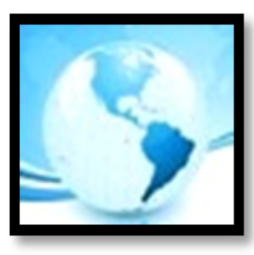

\section{MALAYSIAN ONLINE JOURNAL OF EDUCATIONAL MANAGEMENT (MOJEM)}

to be uphill tasks for many indigenous students. Studies revealed that $30 \%$ of the indigenous students in higher education dropped out from the university due to low academic achievement. The main concerns during this situation were academic adaptations and self-esteem.

Indigenous students often face barriers when socializing in different set of dominant culture. For those with high resiliency towards social changes and with adequate social support at the institution, they have higher chances to persist in higher education. The finding in Table 5 also suggests that academic adaptation and self-esteem are not related. This is because indigenous students have medium and high adaptation but lower self-esteem.

\section{DISCUSSION}

Many new students experienced, at one level in higher education, difficulties in adapting themselves (Andersen, Bunda, \& Walter, 2008). Indigenous students who are first-generation entering higher education level (Pidgeon, 2008) making transition more complicated compared to non-indigenous students. According to Jensen (2011), academic adaptation and socio-emotional adaptation contribute in significant factors of retention among indigenous students in Hawaii. Along with other researchers' findings, Liu (2012) stated that many indigenous freshmen shows great anxiety in academic in their early semesters.

The challenges indigenous students faced during transition into higher education can be explained by the Transition Theory (Anderson, Goodman, \& Schlossberg, 2012), which depicts the challenges from the Situation, Self, Support and Strategies perspectives. Cultural and social interaction issues explain the trigger factor in the Transition Theory and serve as the situation in the theory. These issues fall under the socio-emotional theme in the study. Miller (2011) stated that one challenge for indigenous students is the difficulty in steering the cultural differences between higher education and their indigenous cultures. The obvious cultural barrier influencing indigenous students in succeeding and dropping out from the university is parental support. Parents as the support as suggested in the theory seem to impact whether the students stay on or leave the university. Md Kail (personal communication, August 27, 2015) stated that many indigenous parents refuse to let their children go out from their village and study far from their home. Some parents are supportive in sending their children to study but their children simply refuse further education. Generally, indigenous students felt that pursuing higher education is a waste of money and time; they prefer finding their own income by working around the village.

Lacking in self-regulation and language barriers complicated the academic adaptation of indigenous students. These barriers fall under self in the theory. Literature suggested that there is a significant difference in academic adaptation between the beginning and middle of the semester but not significant between the middle and end of the semester achievement (Rafidah et al., 2009). In this study, pre-diploma students possess lower adaptation compared to diploma students who at least already survive their early years in higher education. Language barriers serve as the challenge in academics as most of their university exam papers are in English language (Hasni, personal communication, August 27, 2015). In this study, pre-diploma students with lower self-esteem have higher pressure in adapting at the university (Rafidah et al., 2009). Lan, Liu, and Hsu (2013) stated in their research that the more social resources the indigenous students have, such as family, peers and teachers' support, the better they adapt socially and academically at post-secondary education which explains the support in the Transition Theory.

\section{CONCLUSION}

It is common for university students to experience high intensity of stress, nervousness or despair for reasons such as cultural differences, pressure from parents to succeed, ethnic identity issues, racism, and discrimination (Zhao, 2012). Syron and McLaughlin (2010) found that adaptation in higher education is often experienced differently by the indigenous students. They stated that if indigenous students have poor academic and socio-emotional 


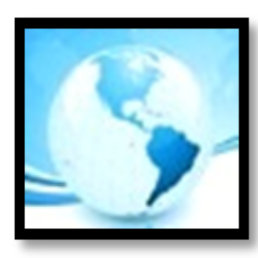

\section{MALAYSIAN ONLINE JOURNAL OF EDUCATIONAL MANAGEMENT (MOJEM)}

adjustment, the probability of them dropping out is high. Hence, indigenous students need to be equipped with effective strategies to adapt to the new challenges in the university or else they will risk developing psychological issues which are very common among ethnic minority students (Sharifah, Samsilah, Aminuddin, Kamaruddin, Mohamad \& Jaimah, 2011). The findings of this study were congruent with past studies (Purdie \& Buckley, 2010). Indigenous students are facing adaptation and low self-esteem issues. To understand these challenges, the students' demographic profile must be taken into account. This study discovered that indigenous students with certain demographic profiles (e.g., female, first-generation, first year students, in pre-diploma programs) seem to be more vulnerable to the challenges of higher education. Unfortunately, university has not customarily spent on measures to support indigenous students during transitioning into higher education and during their university enrolment (Whalan \& Wood, 2012). Hence, the lack of institutional support is among the challenges that indigenous students have to endure. In the case of the selected Malaysian public universities, academic support may be provided to enhance indigenous students' English language proficiency, to help them adapt academically. In terms of socio-emotional adaptation and low-esteem issues, counseling intervention may be provided to help them adapt social-emotionally.

\section{ACKNOWLEDGEMENT}

This study is supported by the Short-Term Research Grant, Universiti Sains I (USM). Grant No: 304/PGURU/6313165

\section{REFERENCES}

Anderson, C., Bunda, T., \& Walter, M. (2008). Indigenous higher education: The role of universities in releasing the potential. Australian Journal of Indigenous Education, 37 (1), 1-8

Anderson, M. L., Goodman, J., \& Schlossberg, N. K. (2012). Counselling adults in transition: Linking Schlossberg's theory with practice in a diverse world (4th ed.). New York, NY: Springer.

Baker, R. W., \& Siryk, B. (1989). Student Adaptation to College Questionnaire Manual. Los Angeles, CA: Western Psychological Services.

Biddle, N., \& Cameron, T. (2012). Potential factors influencing Indigenous education participation and achievement. Adelaide, Australia: National Centre for Vocational Education Research.

Creswell, J. W. (2013). Qualitative, quantitative and mixed methods approaches (4th ed.). Thousand Oaks, CA: Sage.

Cho, Y. J., Mallinckroft, B., \& Yune, S. K. (2010). Collectivism and individualism as bicultural values: South Korean undergraduates' adjustment to college. Asian Journal of Counseling. 17, (1-2), 81-104.

Hasni, H. (2015, August 27). Personal Interview.

Graff, C. G. (2011). Course selection theory and college transition seminars: An adaptation of college choice models to explain first- year students' course enrolment behavior. (Unpublished Ph.D thesis, University of lowa).

Gallop, C. J., \& Bastien, N. (2016). Supporting success: Aboriginal students in higher education. Canadian Journal of Higher Education, 46(2), 206-224. 


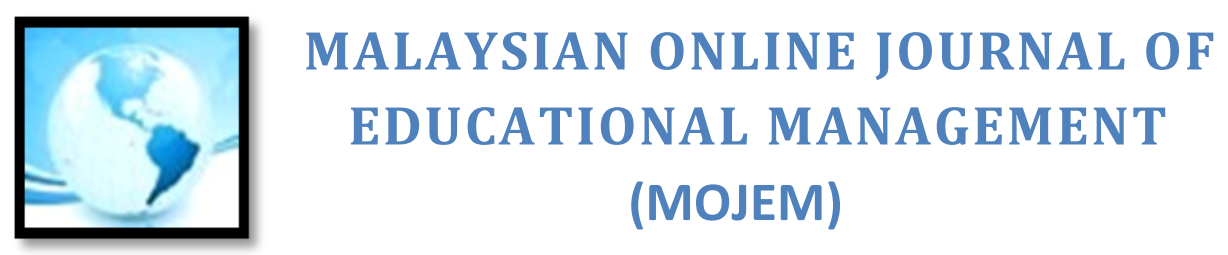

Heatherton, T. F., \& Polivy, J. (1991). Development and validation of a Scale For Measuring State Self-Esteem. Journal of Personality and Social Psychology, 60(6), 895-910.

Ivonkova, N. V., Creswell, J. W., \& Stick, S. L. (2006). Using mixed-methods sequential exploratory design: From theory to practice. Field Method, 18(1), 3-20.

Jensen, U. (2011, February). Factors influencing students' retention in Higher Education. Summary of influential factors in degree attainment and persistence to career or further education for at-risk/ high educational need students. Honolulu, HI: Pacific Policy Research Centre, Kamehameha schools- research \& evaluation division.

Lai, C. S. (2014). College freshmen's self-efficacy, effort regulation, perceived stress and their adaptation to College. Asian Journal of Humanities and Social Sciences, 2(2) 107-117.

Lan, C. J, Liu, R. L., Hsu, L. M. (2013). The study of learning process, campus adaptation and culture adjustment of college Nursing aboriginal students in Taiwan: Combine both longitudinal and cross-sectional methods. Journal of Modern Education Review. 3(8), 587-603.

Lenzerini, F. (2010). Helping indigenous students to finish higher education in non- indigenous higher education under Chinese control. In 4th International Traditional Knowledge Conference. New Zealand. 6-9 June 2010 (13).

Liu, R. L. (2012). The process of coping with changes: A study of learning experiences for the aboriginal Nursing freshmen. New Horizon in Education, 60(1) 1-12.

Md. Kail I. M. N. (2015, August 27). Personal Interview

Miller, C. D. (2011). Biculturalism among indigenous college students. All Theses and Dissertations. Paper 2763. Brigham Young University, Provo.

Mohd. Noorazli, M. N. (2015). Jabatan Kebajikan Orang Asli (JAKOA). Kuala Lumpur.

Pechenkina, E., Kowal, E., \& Paradies, Y. (2011). Indigenous Australian students' participation rates in higher education: Exploring the role of universities. The Australian Journal of Indigenous Education, 40 (1), 59 68.

Pidgeon, M. (2008). Pushing against the margins: Indigenous theorizing of "Success" and retention in higher education. Journal of College Student Retention, 10(3), 339-360.

Purdie, N., \& Buckley, S. (2010). School attendance and retention of indigenous Australian students. Issues paper no. 1 produced for the Closing the Gap Clearinghouse.

Primus, D., \& Abdullah, M. N. L.Y. (2015). Indigenous students' participation at higher education: Unveiling their psychological and non-psychological challenges. In 3rd International Conference on Educational Research and Practice. Putrajaya, 25-26 August 2015 (668-675). 


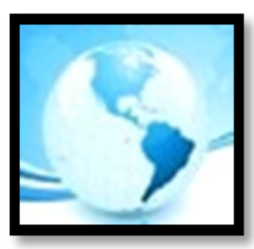

\section{MALAYSIAN ONLINE JOURNAL OF EDUCATIONAL MANAGEMENT (MOJEM)}

Rafidah, K., Azizah, A., Norzaid, M. D., Chong, S. C., Salwani, M. I., \& Noraini, I. (2009). The impact of perceived stress and stress factors on academic performance of pre-Diploma Science students: A Malaysian study. International Journal of Scientific Research in Education, 2(1), 13-26.

Sharifah M. N., Samsilah R., Aminuddin M., Kamaruddin Hj. A. H., Mohamad, A. M.A., \& Jaimah, A. M. (2011). Dropout prevention initiatives for Malaysian Indigenous Orang Asli children. The International Journal on School Disaffection, 8(1), 42-56.

Sullivan, A. (2008). Exploring the acculturation of Taiwanese students in an Australian university: English selfconfidence, well-being and friendships. Griffith working papers in pragmatics and intercultural communication, 1(2), 119-136.

Syron, M., \& McLaughlin, J. (2010). Indigenous knowledge: Informing and supporting indigenous students during their first year at university. Paper presented at the First Year in Higher Education Conference, Adelaide, Australia.

Whalan, F., \& Wood, K. (2012). Action learning based professional development: Being more responsive to aboriginal cultures and histories. In N. Burridge, F. Whalan, \& K. Vaughan (Eds.), Indigenous education: $A$ learning journey for teachers, schools and communities (pp. 23-32). Rotterdam, The Netherlands: Sense Publishers.

Zhao, Xin. (2012). Asian college students' perceived peer group cohesion, cultural identity, and college adjustment. All Graduate Theses and Dissertations. Paper 1336. 